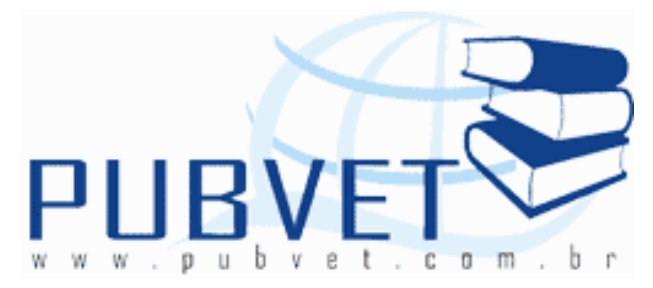

PUBVET, Publicações em Medicina Veterinária e Zootecnia.

\title{
Influência do manejo pré-abate na qualidade da carne suína visando o bem-estar animal
}

\section{Rafaeli Gonçalves Leite ${ }^{1}$, Vagno Júnior de Oliveira ${ }^{1}$, Mariana Cristina de Jesus Pinheiro ${ }^{1}$, Amorésio Souza Silva Filho ${ }^{2}$, Angela Aparecida da Fonseca ${ }^{2}$, Joab Vinícius Martins de Siqueira ${ }^{3}$, Giselde Marques Angreves Silva ${ }^{4}$}

${ }^{1}$ Zootecnista, Universidade do Estado de Mato Grosso, Campus Universitário de Pontes e Lacerda

2 Mestrando em Ciência Animal, Universidade Federal de Mato Grosso, Campus Cuiabá

${ }^{3}$ Agrônomo, Universidade do Estado de Mato Grosso

${ }^{4}$ Professora do Departamento de Zootecnia da Universidade do Estado de Mato Grosso (UNEMAT), Rodovia 174, km 209, caixa postal 181, Pontes e Lacerda - MT.

\section{Resumo}

A carne suína é a carne mais consumida no mundo, e o mercado consumidor dessa carne tem se tornado cada vez mais exigente quanto à qualidade e à origem dos animais consumidos principalmente em questões de bem-estar em que esses animais foram produzidos. O estudo realizado demonstra as características de qualidade que a carne suína apresenta e abrange os momentos em que os animais mais sofrem estresse, demonstrando que os animais que são transportados na parte inferior do caminhão sofrem maiores 
LEITE, R.G. et al. Influência do manejo pré-abate na qualidade da carne suína visando o bemestar animal. PUBVET, Londrina, V. 8, N. 5, Ed. 254, Art. 1681, Março, 2014.

problemas relacionados ao estresse e ainda que animais que apresentam o gene halotano na sua carga genética são mais susceptíveis ao estresse. Discute ainda qual a influência do estresse na qualidade da carne e quais as maneiras de evitar esses momentos sendo extremamente necessário ocorrer mudanças quanto ao manejo realizado com os suínos tanto no setor de produção quanto no setor de abate.

Palavras-chave: anomalias, consumo, jejum, transporte.

\title{
Influence of management pre-slaughter in the quality of pork aiming at animal welfare
}

\begin{abstract}
Pork is the most consumed meat in the world, and the consumer market of the meat has become increasingly demanding about the quality and the origin of animals consumed mainly on issues of welfare in these animals were produced. The study demonstrates the quality that has pork and cover the times when the animals suffer more stress, demonstrating that the animals are transported at the bottom of the truck suffer major problems related to stress and that animals have the halothane gene in its genetic background are more susceptible to stress. It also discusses the influence of stress on meat quality and what are ways to avoid these moments occur is extremely necessary changes regarding the treatment is carried out with the pigs in both the production sector and in the slaughter industry.
\end{abstract}

Keywords: anomalies, consumption, fasting, transport.

\section{Introdução}

Diante de indicadores sociais e econômicos como o volume das exportações, a participação brasileira no mercado mundial e o número de empregos direto ou indireto, demonstra a evolução da suinocultura brasileira, sendo que esse crescimento se dá principalmente às tecnologias implantadas e a disponibilidade interna de matéria-prima (milho e soja principalmente) e 
LEITE, R.G. et al. Influência do manejo pré-abate na qualidade da carne suína visando o bemestar animal. PUBVET, Londrina, V. 8, N. 5, Ed. 254, Art. 1681, Março, 2014.

ainda devido às restrições ambientais impostas a países com participação importante no setor como a Dinamarca, dando assim espaço para o crescimento e destaque brasileiro (TALAMINI e FERREIRA, 2006).

Cerutti (2003) já dizia que o Brasil estará entre as três maiores potências de exportação de carne até 2012, esse fato exige pontos de organização da cadeia produtiva para a segurança alimentar e a produção serem atingidos dando total importância à genética, sanidade, biossegurança, bem estar animal e alimentação, visto que esses têm relação com o rendimento e a qualidade final da carne, contudo, estabelecer regularidade quanto ao bem estar animal durante a criação, carregamento e transporte pré-abate é vital para a qualidade do produto final.

A agroindústria da suinocultura junto com a comunidade cientifica possuem o desafio de chegar à produção de maior quantidade de carne de melhor qualidade para poder atender ao mercado consumidor futuro e ainda garantir a viabilidade econômica de toda a cadeia (SILVEIRA, 2005).

No assunto suinocultura industrial e qualidade de carne o tema mais atual é o bem estar animal, devido ao fato dos países europeus estarem cada vez mais preocupados com a origem dos animais dos quais consomem a carne, a exigência é que a carne comercializada seja oriunda de animais saudáveis que tenham sido criados em um sistema que respeite seu bem estar, o não cumprimento dessa exigência além de outros problemas, afeta a importação da carne suína brasileira (SANTOS, 2004).

A solução para que a criação de suínos visando o bem estar aconteça de fato depende de toda a cadeia produtiva, desde o suinocultor até a indústria de abate, principalmente deve ser considerado que o suinocultor na maioria das vezes trabalha conforme é possível sobreviver perante o mercado competitivo. Apesar de todas as dificuldades enfrentadas pelo produtor, o problema com as situações de estresse continua de forma acentuada, do embarque e só termina de fato no abate (BRAUN, 2000).

Quanto ao consumo, a carne suína é a proteína animal mais consumida no mundo, devido provavelmente ao alto valor nutritivo e à facilidade de 
LEITE, R.G. et al. Influência do manejo pré-abate na qualidade da carne suína visando o bemestar animal. PUBVET, Londrina, V. 8, N. 5, Ed. 254, Art. 1681, Março, 2014.

separação da gordura, porém ainda ocorre, principalmente no Brasil, o preconceito com o consumo da carne devido à mitos que vem sendo cada vez mais ignorados, pois do ponto de vista nutricional essa carne apresenta inúmeras vantagens e quando consumida da maneira e quantidade correta não causa nenhum dano. A qualidade dessa carne é determinada por fatores ambientais e pela genética. A textura, cor, sabor, suculência e aroma são características influenciadas pelo processo bioquímico que ocorre durante a transformação do músculo em carne (SARCINELLI et al., 2007).

Existem anomalias que a carne suína pode apresentar devido à sua carga genética que pode torná-la mais susceptível ao estresse, sendo as principais anomalias, carnes com característica PSE (pale, soft e exudative - pálida, flácida e exudativa) e DFD (dark, firm, dry - escura, dura e seca), essas características tornam a carne imprópria para o consumo, podendo ser utilizada apenas em produtos industrializados, sendo possível a utilização da carne PSE em salames e salsichas na proporção de 30\% de PSE para 70\% de carne normal e quanto a carne DFD também pode ser usada nessa proporção na fabricação de embutidos exceto em salame e presunto cru devido a grande retenção de água que essa carne apresenta (TERRA e FRIES, 2000).

Diante dessas informações, o objetivo desse trabalho é compreender as características que tornam os suínos geneticamente mais susceptíveis ao estresse, quais os danos que o estresse pode causar na carne e ainda entender qual a importância do manejo pré-abate realizado corretamente, sempre visando medidas de bem-estar.

\section{Importância da carne suína}

A carne suína é a proteína animal mais produzida e consumida no mundo, possuindo características nutricionais extremamente interessantes, sendo constituída de $72 \%$ de água, $20 \%$ de proteína, $7 \%$ de gordura, $1 \%$ de minerais e menos que $1 \%$ de carboidratos, além de ser importante fonte de vitaminas como a B1, B2, B6, B12, A e C (BRAGAGNOLO e AMAYA, 2002). No Brasil o consumo tem aumentado com a quebra de mitos que cercam a carne 
LEITE, R.G. et al. Influência do manejo pré-abate na qualidade da carne suína visando o bemestar animal. PUBVET, Londrina, V. 8, N. 5, Ed. 254, Art. 1681, Março, 2014.

suína, isso se deve ao marketing que está esclarecendo para a população que essa carne além de ser importante fonte de vitaminas, possui baixo nível de colesterol, está esclarecendo ainda que esses animais ao invés de serem criados em locais sujos e com restos de comida recebem alimentação balanceada, de qualidade e são criados em granjas monitoradas com rígido controle sanitário (TRAMONTINI, 2000).

Sarcinelli et al. (2007) preconizam como uma das maiores vantagens da carne suína o fato de $70 \%$ da gordura existente estar localizada no toucinho, abaixo da pele, isso possibilita que durante o preparo da carne, a gordura possa ser facilmente retirada, assim, a alimentação será ainda mais eficiente quanto à redução do valor calórico e lipídico.

\section{Características da carne suína}

De acordo com Cerutti (2003) a carne suína tem sido reconhecida pelos consumidores brasileiros cada vez mais por suas qualidades sensoriais, visuais (fresca, rosa-avermelhada, com alta capacidade de retenção de água, macia, suculenta) e também nutritivas, constituindo um alimento com as seguintes características:

- $\quad$ Rico em proteínas, nutritivo e saboroso;

- Fonte de vitaminas do complexo B (tiamina, riboflavina, vitamina B6 e B12);

- $\quad$ Fonte de minerais (cálcio, fósforo, zinco e ferro);

- Importante teor de potássio, tornando a carne mais indicada para quem tem alta pressão sanguínea (o potássio ajuda a diminuir o nível de sódio);

- Apenas $30 \%$ da gordura total estão presentes no músculo, $70 \%$ estão abaixo da pele;

- $\quad$ o teor de gordura no músculo é de 1,1 a $2,4 \%$, sendo equivalente à carne de aves;

- Da gordura total presente, $65 \%$ é gordura insaturada;

- É rica em ácido Linoleico, neutralizando de forma eficaz os efeitos negativos do ácido Palmítico (gordura saturada); 
LEITE, R.G. et al. Influência do manejo pré-abate na qualidade da carne suína visando o bemestar animal. PUBVET, Londrina, V. 8, N. 5, Ed. 254, Art. 1681, Março, 2014.

- $\quad$ Nível de colesterol semelhante às carnes de bovinos e aves.

O suíno possui carne de cor uniforme, avermelhada e rosada e essa coloração é determinada pelos pigmentos de mioglobina existentes nos músculos, e ainda a quantidade desses pigmentos pode ser influenciada pelo sexo, espécie, idade e atividade física exercida pelo animal (SARCINELLI, et al., 2007). Terra e Fries (2000) comentaram que a genética é grande responsável pela coloração da carne, uma vez que a coloração nada mais é que a concentração e o estado químico dos pigmentos musculares, por exemplo, a raça Landrace possui maior quantidade de pigmento no músculo que a raça Duroc.

Ainda a respeito da coloração da carne, Schafer (2001) ressalta que é preferível que a carne seja de cor uniforme e que cortes que apresentam cor cinza pálido ou vermelho escuro não são interessantes, sendo importante lembrar que músculos dispostos próximos ao osso apresentam com normalidade coloração mais escuros que os demais.

Falando sobre maciez, Sarcinelli et al. (2007) consideram esse fator determinante para o critério de qualidade imposto pelos consumidores e esse pode ser afetado por fatores ante-mortem: idade, sexo, nutrição, exercício, estresse antes do abate, presença de tecido conjuntivo e comprimento do sarcômero, ou ainda por fatores post-mortem: estimulação elétrica, rigor mortis, esfriamento da carcaça, maturação, método e temperatura de cozimento, e pH final da carne.

A textura da carne é de extrema importância para o consumidor, uma vez que a carne firme e magra é preferível, sendo totalmente inaceitável que ela apresente características PSE (SCHAFER, 2001).

Uma das características de grande importância na qualidade da carne é a sua capacidade de retenção de água, ou seja, capacidade que o músculo tem de reter água durante o corte, trituração, prensagem e aquecimento e quando essa capacidade dos tecidos musculares é baixa a perda de água é grande 
LEITE, R.G. et al. Influência do manejo pré-abate na qualidade da carne suína visando o bemestar animal. PUBVET, Londrina, V. 8, N. 5, Ed. 254, Art. 1681, Março, 2014.

tendo como consequência a perda de peso durante o período de armazenamento (SARCINELLIet al., 2007).

\section{Transformação do músculo em carne}

O processo da transformação do músculo em carne envolve várias alterações no metabolismo celular e na estrutura proteica, como por exemplo, o esgotamento das reservas de adenosina trifosfato (ATP), diminuição do $\mathrm{pH}$ ou acidificação, queda da temperatura muscular,aumento da concentração de íons cálcio no citosol, rigor mortis entre outras alterações (LAWRIE, 1974, JUDGE et al., 1989 citado por RUBENSAM, 2000).

Rubensam (2000) cita que já está bem determinado que o metabolismo post-mortem que resulta na hidrólise do glicogênio muscular é a variável que determina a qualidade da carne suína fresca, estando diretamente ligado com o gene halotano e o gene do rendimento napole que afetam o processo de diminuição do $\mathrm{pH}$ muscular.

O glicogênio está presente em todos os tecidos, sendo evidenciada a sua importância no fígado e no músculo estriado onde apresenta papel importante na conversão do músculo em carne e ainda a concentração do glicogênio antes do abate define a formação do ácido lático e consequentemente na queda do $\mathrm{pH}$. Estão presentes no citoplasma das células hepáticas e nas fibras musculares, enzimas que são responsáveis pela síntese e quebra do glicogênio, sendo que a insulina estimula a síntese do glicogênio e a adrenalina, enquanto glucagon estimula a quebra. A fosforilase $b$ e a fosfofrutoquinase são as primeiras enzimas que regulam a glicólise post-mortem. A glicólise é o processo que envolve todas as etapas da conversão do glicogênio ou glicose muscular em ácido pirúvico ou ácido lático (ROÇA, 2001).

Considerando primeiramente o animal vivo esse processo é o meio mais rápido de obtenção de ATP em condições anaeróbias. A segunda parte desse processo é o ciclo de Krebs, uma continuação da via glicolítica e requer oxigênio, esse tem como função a conversão dos ácidos pirúvico e lático em gás carbônico e íons hidrogênio, após essa conversão, o gás carbônico é 
LEITE, R.G. et al. Influência do manejo pré-abate na qualidade da carne suína visando o bemestar animal. PUBVET, Londrina, V. 8, N. 5, Ed. 254, Art. 1681, Março, 2014.

eliminado pela corrente sanguínea e os íons hidrogênio entram na terceira parte do processo chamada de fosforilação oxidativa ou cadeia citocrômica mitocondrial que resulta em ATP, e assim a velocidade do consumo do ATP determina à velocidade da degradação do glicogênio, em consequência a formação do produto final do metabolismo anaeróbio que é o ácido lático, portanto a forma mais eficiente de saber o consumo de ATP é medindo o pH. Em suínos a velocidade da queda do pH é rápida atingindo 5,6 à 5,7 de 6 à 8 horas post-mortem e 5,3 à 5,7 24 horas post-mortem, sendo que valores diferentes disso causam anomalias na carne (ROÇA, 2001) concordando com (BRIDI, 2005).

\section{Bem-estar animal em suínos}

O bem estar animal tem sido uma ferramenta de extrema importância para garantir que os animais possam ter livre expressão de comportamento para seu crescimento, porém a pressão de seleção genética imposta sobre os suínos para a obtenção de uma carne mais magra com animais de crescimento rápido resultou também em suínos mais susceptíveis ao estresse, principalmente durante momentos incomuns em sua vida como, por exemplo, momentos que ocorrem após a terminação (CERUTTI, 2003).

Assim como na criação de outras espécies, na suinocultura a preocupação com o bem-estar está cada vez mais intensa e cobrada pelos consumidores, que exigem que o animal sofra o mínimo de estresse possível durante sua criação (Figura 1), se estendendo no transporte e ao abate, entretanto, os sistemas de criação que dominam hoje a suinocultura foram projetados para maximizar a produção animal e melhorar lucros para os suinocultores sem a pretensão de prejudicar o conforto desses animais, sendo preciso para atender esse novo mercado, que durante a criação, os suinocultores consigam diminuir os níveis de estresse para que possa atingir o atual mercado exigente, mas o problema se estende além da granja, sendo o transporte responsável por grande parte dos transtornos que envolvem as questões de bem-estar em suínos (BRAUN, 2000). 
LEITE, R.G. et al. Influência do manejo pré-abate na qualidade da carne suína visando o bemestar animal. PUBVET, Londrina, V. 8, N. 5, Ed. 254, Art. 1681, Março, 2014.

No Brasil a tendência é que os colaboradores de granjas recebam treinamento que os possibilitem entender a importância do bem-estar desses animais e que as granjas também se adéquem a medidas de prevenção sanitária, segurança alimentar e meio ambiente, isso fará com que futuramente a carne suína seja oferecida como carne de animais criados dentro das medidas de bem-estar e em granjas que respeitam questões ambientais, sendo que esses pontos possibilitarão um novo olhar dos consumidores sobre a suinocultura (DALLA COSTA et al. 2005).

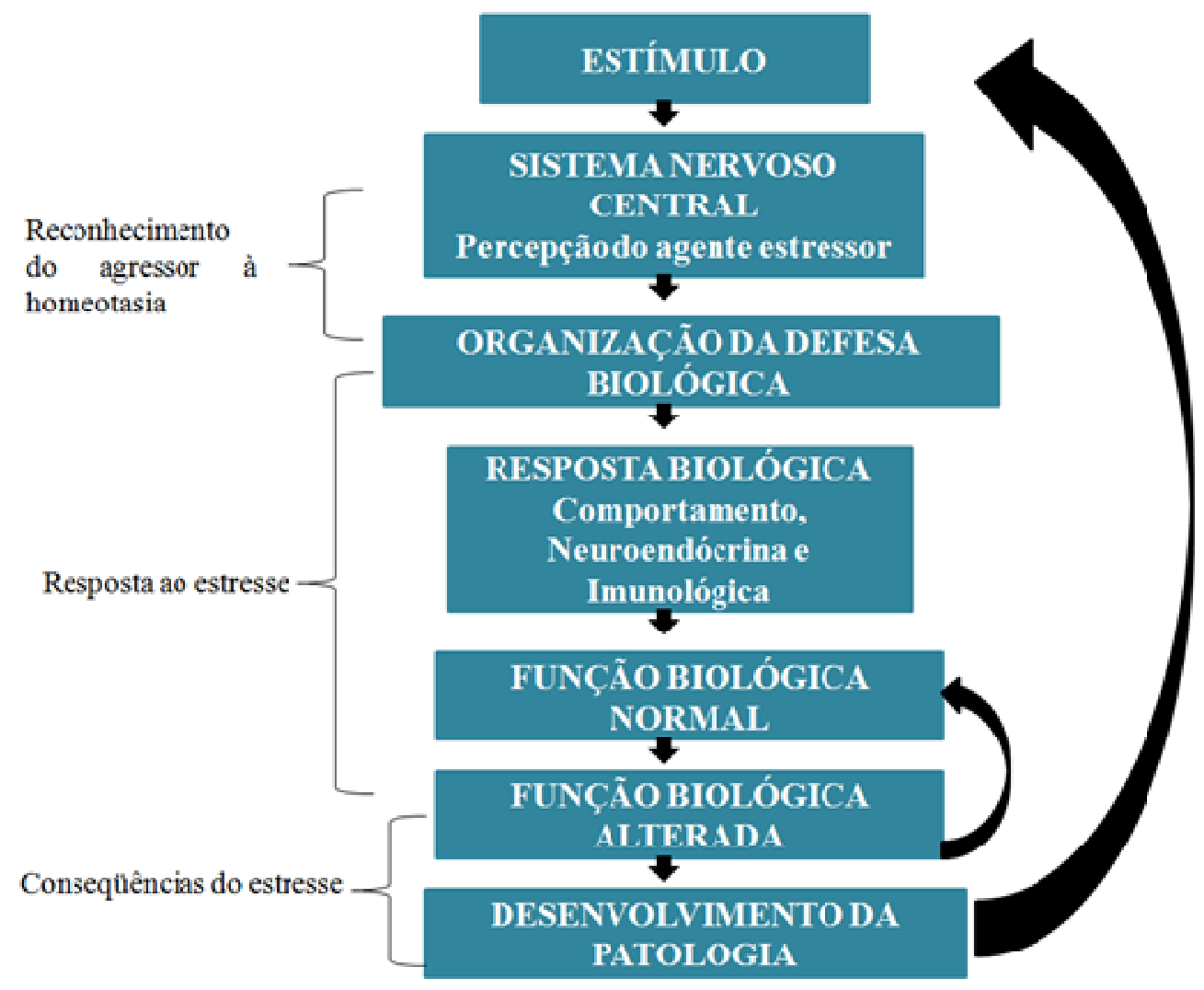

Figura 1.Demonstração esquemática do mecanismo da resposta biológica dos animais ao estresse.

Fonte: Adaptado de Moberg (2000) citado por Ludtkeet al. (2010). 
LEITE, R.G. et al. Influência do manejo pré-abate na qualidade da carne suína visando o bemestar animal. PUBVET, Londrina, V. 8, N. 5, Ed. 254, Art. 1681, Março, 2014.

Na Inglaterra o Farm Animal WelfareCouncil (FAWC, 1992), impulsionado pelo livro Animal Machine publicado em 1964 escrito por Ruth Arrison que denunciava questões de maus tratos em animais de criação, definiu o bemestar animal mediante às cinco leis da liberdade, sendo elas:

I. Liberdade fisiológica: Os animais não devem ser privados de água e alimento e devem manter suas funções fisiológico-orgânicas em equilíbrio, sendo capazes de crescer e de se reproduzir normalmente;

II. Liberdade ambiental: As edificações devem ser adaptadas para que os animais sejam mantidos em ambientes próximos ao seu habitat natural, sendo livres para desenvolver suas características e capacidades naturais;

III. Liberdade sanitária: Os animais devem estar livres de doenças, injúrias e sem sinais de má nutrição;

IV. Liberdade comportamental: No local onde estiverem devem ter a possibilidade de exprimir comportamentos normais;

V. Liberdade psicológica: Ausência de medo, frustração e ansiedade, pois isto resulta em comportamentos anormais e problemas de bem-estar.

Animais selecionados para alta produtividade e criados em locais que pressionam o alto rendimento passam por situações com alto sofrimento, por exemplo, porcas selecionadas para alta prolificidade (25 leitões por ano em gaiolas parideiras com mínimo espaço), apresentam quadros que evidenciam o sofrimento psicológico e problemas físicos como anomalias nas articulações, contusões nas juntas, problemas respiratórios e úlceras gástricas, isso faz com que esses animais sejam descartados cada vez mais cedo, porém os prejuízos relacionados a esses problemas ocorrem em toda a cadeia, da produção ao abate, então não é só no setor de produção que as práticas de bem estar animal devem ser implantadas, devendo ocorrer com mais atenção durante o manejo, sobre os equipamentos, instalações e treinamento de colaboradores que participam de alguma forma dessa cadeia (MACHADO FILHO e HOTZEL, 2000).

O aumento da frequência cardíaca, a atividade adrenal, a atividade adrenal após desafio através do hormônio adrenocorticotrófico ou resposta 
LEITE, R.G. et al. Influência do manejo pré-abate na qualidade da carne suína visando o bemestar animal. PUBVET, Londrina, V. 8, N. 5, Ed. 254, Art. 1681, Março, 2014.

imunológica reduzida após desafio, são fatores que podem indicar que esses animais passaram por condições de bem-estar comprometidas (BROOM e MOLENTO, 2004).

Como alternativas para melhorar o bem-estar dos suínos nos sistemas de criação confinado que é o mais utilizado hoje, Machado Filho e Hotzel (2000) indicam:

- Uso de objetos como correntes e brinquedos para quebrar a monotonia dos ambientes com o objetivo de reduzir o canibalismo;

- Uso de palha sobre o piso, evitando o uso de piso ripado, também com o objetivo de reduzir o canibalismo;

- Área mínima de $1 \mathrm{~m}^{2}$ por suíno na terminação, com palha ao lado do comedouro, com bebedouro do lado oposto, isso faz com que os animais separem o local de excreção do local de descanso;

- Gaiolas parideiras com espaço suficiente para as porcas se virarem e palha para que possam fazer ninho. Porcas nesse estágio passam por uma mudança hormonal drástica, fazendo com que também ocorram mudanças comportamentais, sendo a maior delas a necessidade da porca fazer ninho para parir e poder aconchegar os leitões inviabilizando a necessidade do uso de aquecedores para os leitões, e no caso de não haver a palha para a realização desse comportamento, os aspectos fisiológicos ligados com a maternidade podem ser prejudicados podendo resultar em amamentação ineficiente, canibalismo e até mesmo agressão voltada aos leitões.

Zanella e Duran (2000) consideram como perspectivas do bem-estar em suínos, a eliminação do uso de bastão elétrico além de maiores pesquisas para encontrar soluções no embarque e no transporte desses animais, uma vez que essa é a etapa que mais possibilita a existência de alterações de comportamento que prejudicam o bem-estar.

\section{Problemas da carne suína relacionados ao estresse e a genética}

Com relação aos fatores que interferem na qualidade da carne é importante bastante atenção quanto ao fator intrínseco e individual de cada 
LEITE, R.G. et al. Influência do manejo pré-abate na qualidade da carne suína visando o bemestar animal. PUBVET, Londrina, V. 8, N. 5, Ed. 254, Art. 1681, Março, 2014.

animal, como por exemplo, sua pré-disposição ao estresse que ocorre durante toda sua vida e principalmente no manejo pré-abate (TERRA e FRIES, 2000).

Embora não seja possível afirmar que a má qualidade da carne suína está sempre ligada a fatores estressantes, esses na maioria das vezes resultam sim em carne suína de pior qualidade que quando não está relacionada com problemas que possam ser diagnosticados na carne crua, fornecem uma carne mais dura de pior palatabilidade, sabendo que esses fatores se evidenciam momentos antes do abate, tem-se então a importância de um manejo préabate bem realizado (WARRIS e BROW, 2000).

Quanto à carga genética dos suínos, o gene halotano é responsável pela maior predisposição de algumas raças aos estresses relacionados ao manejo na granja e principalmente ao manejo que antecede o abate, sendo que esse gene apresenta efeito negativo quanto à qualidade da carne, mesmo que esteja presente de forma recessiva na carga genética do animal (CULAU et al., 2002).

\section{Carne PSE}

A carne pale, soft e exudative ou pálida, flácida e exudativa (PSE) apresenta grandes perdas para a indústria de carne suína por apresentar características como baixa capacidade de retenção de água, textura flácida e cor pálida, esses provocam perdas importantes de água durante o seu processamento e essa característica ocorre principalmente devido ao processo de consumo acelerado de glicogênio, fazendo com que o $\mathrm{pH}$ muscular chegue a menor que 5,8 em um momento que a temperatura corporal se encontra maior que $38^{\circ} \mathrm{C}$, com isso ocorre um processo de desnaturação proteica levando ao comprometimento das propriedades funcionais da carne (CERUTTI, 2003).

Para Chevillon (2000) o processo de acidificação do músculo ocorre com a transformação da glicose em ácido láctico no período de abate, e o nível do estresse que o suíno é submetido é que determinará a velocidade dessa transformação. Quanto maior o nível de estresse maior será a velocidade 
LEITE, R.G. et al. Influência do manejo pré-abate na qualidade da carne suína visando o bemestar animal. PUBVET, Londrina, V. 8, N. 5, Ed. 254, Art. 1681, Março, 2014.

dessa transformação, e a queda rápida do pH provoca desnaturação das proteínas do músculo resultando em carne com característica PSE.

Sarcinelli et al (2007), associam a carne PSE com fatores relacionados a uma má realização do manejo pré-abate e se caracteriza pela rápida queda do $\mathrm{pH}$, menor que 5.8, o que torna a carne pálida e com baixa capacidade de retenção de água, resultando em maior perda de peso (Figura 2). Outra característica dessa carne é a perda da capacidade de retenção de água, o que resulta a maior perda de peso podendo ser usada apenas para industrialização na proporção de 30\% carne PSE para $70 \%$ carne normal e de preferência utilizada apenas na fabricação de salames (TERRA e FRIES, 2000).

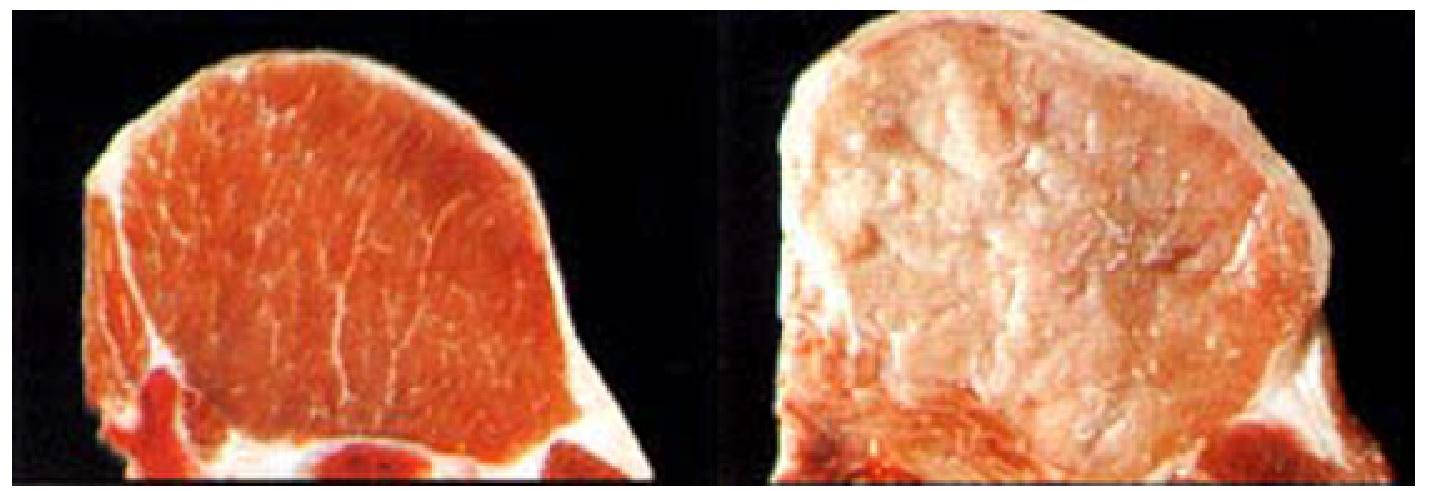

Figura 2. Carne normal comparada com a carne PSE. Fonte: Adaptado de Sarcinelli et al. (2007).

Para Warris e Brown (2000), o estresse imediatamente antes do abate resulta nesse tipo de carne, e suínos que são abatidos em sistemas de manejo que permitem alto nível de estresse apresentaram em seu estudo maior incidência de carne PSE devido justamente ao estresse ocorrido momentos antes do abate, esse estresse foi comprovado pelas altas concentrações de lactato e da enzina creatina fosfoquinase (CPK), e esses ainda produziram mais carne com característica PSE segundo medidas obtidas pelo método PQM (PorkQuality Meter- Medidor da Qualidade da Carne Suína) em que medidas mais altas indicam carne PSE, podendo ser observado na tabela 1. 
LEITE, R.G. et al. Influência do manejo pré-abate na qualidade da carne suína visando o bemestar animal. PUBVET, Londrina, V. 8, N. 5, Ed. 254, Art. 1681, Março, 2014.

Tabela 1. Índices de estresse e de qualidade de carne em suínos abatidos em abatedouros avaliados subjetivamente como tendo sistemas de manuseio de alto ou baixo estresse.

\begin{tabular}{|c|c|c|c|}
\hline & $\begin{array}{l}\text { Suínos abatidos } \\
\text { em sistemas de } \\
\text { baixo estresse }\end{array}$ & $\begin{array}{l}\text { Suínos abatidos } \\
\text { em sistemas de } \\
\text { alto estresse }\end{array}$ & \\
\hline $\begin{array}{l}\text { Lactato no } \\
\text { plasma (mg \%) }\end{array}$ & 64 & 140 & $* * *$ \\
\hline CPK plasma (U/I) & 965 & 1436 & $*$ \\
\hline $\begin{array}{l}\text { Lactato > } 100 \\
\mathrm{mg} \%\end{array}$ & $6 \%$ & $69 \%$ & \\
\hline $\begin{array}{l}\text { Valor sonda PQM } \\
\text { N PQM }>=6\end{array}$ & $\begin{array}{l}3.8 \\
7.5 \%\end{array}$ & $\begin{array}{l}4.7 \\
16.8 \%\end{array}$ & $* * *$ \\
\hline
\end{tabular}

\section{Carne DFD}

Evidenciada pela cor escura, sendo ainda carne firme e seca com média de $\mathrm{pH}$ superior a 6,2, essas características aumentam o risco de proliferação de micro organismos e ainda veda as possibilidades dessa carne ser utilizada para a produção de industrializados pela alta capacidade de retenção de água que apresenta (CERUTTI, 2003).

Para Warris e Brown (2000), estresse ocorrido em longo prazo normalmente esgota as reservas de glicogênio e resulta em carne DFD (dark,firm, dry - escura, dura e seca), em seu estudo os suínos com mais arranhões e danos na pele apresentaram maiores níveis de cortisol e de CPK (Tabela 2). Estresse ocorrido momentos antes do abate e da sangria resultam nesse tipo de alteração na carne, sendo que o esgotamento das reservas de glicogênio se deve ao estresse e para evitar a ocorrência dessa anomalia podem ser adotadas medidas como, por exemplo, evitar a mistura de lotes de origem diferente, formar lotes com pequeno número de animais, promover o descanso dos animais antes do embarque para o frigorifico e ainda promover transporte e desembarque o mais tranquilo possível (FARIA, 2008). 
LEITE, R.G. et al. Influência do manejo pré-abate na qualidade da carne suína visando o bemestar animal. PUBVET, Londrina, V. 8, N. 5, Ed. 254, Art. 1681, Março, 2014.

Quando a restrição alimentar na granja é maior que 24 horas além de promover a redução de peso, se associada à mistura de lotes aumentam as chances da obtenção de carne DFD. Com a qualidade da carne suína prejudicada por essa condição é gerado maiores custos, uma vez que essa carne tem menor validade no varejo devido à degradação microbiana facilitada (MURRAY, 2000).

Tabela 2. Efeito da briga, evidenciada por danos na pele, sobre o perfil sanguíneo e qualidade da carne em suínos.

\begin{tabular}{llllll}
\hline \multicolumn{5}{c}{ Escores de danos na pele* } \\
\hline $\begin{array}{l}\text { Cortisol } \\
\text { plasmático } \\
(\mathrm{mg} \%)\end{array}$ & 15 & 2 & 3 & 4 & $* * *$ \\
$\begin{array}{l}\text { Plasma } \\
\text { CPK }(\mathrm{U} / \mathrm{l})\end{array}$ & 517 & 16 & 19 & 22 & \\
pHu \\
músculo \\
LD
\end{tabular}

Sarcinelli et al. (2007), comentam que a carne DFD é resultado de um manejo pré-abate errôneo que provoca estresse no animal diminuindo a reserva de glicogênio presente no músculo, isso resulta numa carne com pH maior que 6,2, o que diminui a vida útil da carne e favorece a proliferação de micro organismos. Essa carne é escura, firme e seca (Figura 3), e o maior produtor desse tipo de carne é o transporte mal realizado onde ocorre o maior consumo de glicogênio muscular, o que torna essa carne inadequada até 
LEITE, R.G. et al. Influência do manejo pré-abate na qualidade da carne suína visando o bemestar animal. PUBVET, Londrina, V. 8, N. 5, Ed. 254, Art. 1681, Março, 2014.

mesmo para a industrialização de salame e presunto cru (TERRA e FRIES, 2000).

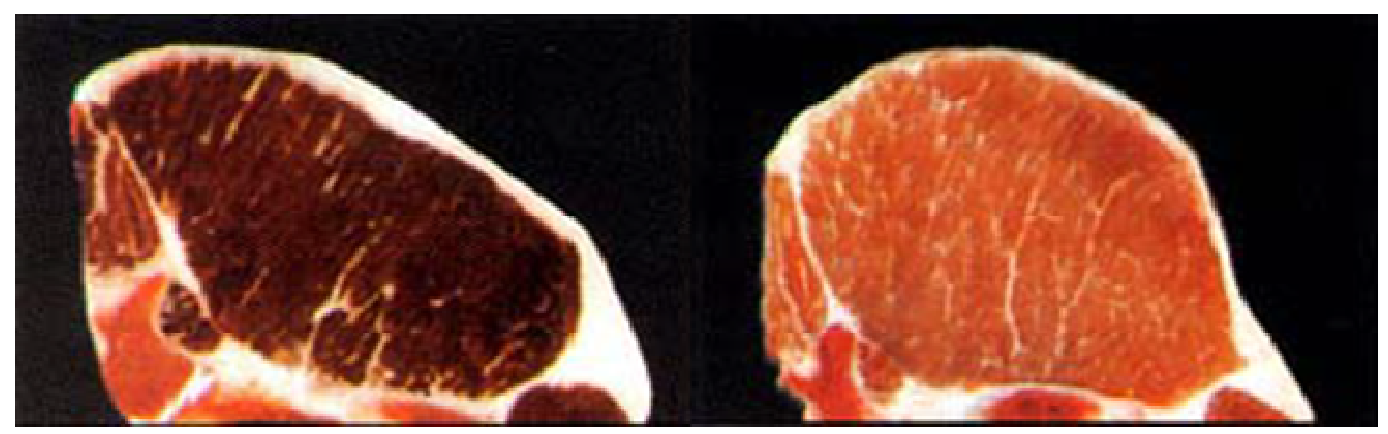

Figura 3. Carne DFD e Carne Normal.

Fonte: Adaptado de Sarcinelli et al. (2007).

\section{Gene Halotano}

O gene halotano surgiu com uma mutação genética dos suínos e esse foi explorado para que possibilitasse maior deposição de carne nos suínos sem que houvesse prejuízos quanto à qualidade da carne, no entanto, vem sido conhecido como gene do estresse pela sua relação com a carne PSE onde na verdade os animais portadores desse gene, sendo a raça Pietran a principal portadora, possuem uma disposição maior ao estresse que os não portadores e essa disposição é ativada pelo manejo errôneo que ocorre no Brasil (FÁVERO e BELLAVER, 2001).

Apesar de ser relacionado com a síndrome do estresse suíno e com a carne PSE, o gene apresenta a vantagem de proporcionar carcaças com maior quantidade de carne magra (CULAU et al., 2002).

Bastos et al. (2001) realizaram um estudo com animais sem presença de gene halotano, animais com gene halotano em homozigose e animais com gene halotano em heterozigose, concluindo que os animais com o gene halotano tanto em homozigose quanto em heterozigose apresentam efeito negativo quanto a coloração da carcaça, indicando que os cruzamentos com animais providos desse gene seja evitado, como podemos ver na tabela 3. 
LEITE, R.G. et al. Influência do manejo pré-abate na qualidade da carne suína visando o bemestar animal. PUBVET, Londrina, V. 8, N. 5, Ed. 254, Art. 1681, Março, 2014.

Com uma opinião um pouco divergente, Bridiet al. (2006) obtiveram resultados em que suínos com gene halotano em heterozigose apresentaram maior perda de água, coloração mais clara e ainda maior quantidade de carne PSE que os suínos com gene halotano em homozigose.

Tabela 3. Médias e erros-padrão das características de carcaça dos animais nos genótipos do gene halotano.

\begin{tabular}{llll}
\hline $\begin{array}{l}\text { Característica da } \\
\text { carcaça }\end{array}$ & \multicolumn{4}{l}{ Genótipo $\left(\mathrm{n}^{\circ}\right)$} \\
\cline { 2 - 4 } & $\mathrm{NN}^{1}(82)^{2}$ & $\mathrm{Nn}(67)$ & $\mathrm{nn}(06)$ \\
\hline $\mathrm{PCQ}^{3}(\mathrm{Kg})$ & $73,80(7,862)^{4}$ & $74,41(7,904)$ & $69,13(8,462)$ \\
$\mathrm{ET}(\mathrm{mm})$ & $21,32(4,650)$ & $20,07(4,290)$ & $21,26(4,895)$ \\
$\mathrm{PM}(\mathrm{mm})$ & $48,58(6,317)$ & $49,30(8,567)$ & $46,20(8,514)$ \\
$\mathrm{CM}(\%)$ & $52,51(2,879)$ & $53,28(2,773)$ & $52,26(3,605)$ \\
$\mathrm{COR}($ absorb) & $51,34(6,033)$ & $50,83(6,981)$ & $55,33(7,916)$ \\
VCOR (\%) & $40,82(12,96)^{\mathrm{a}}$ & $49,77(23,19)^{\mathrm{b}}$ & $53,83(41,619)^{\mathrm{c}}$ \\
\hline 1 NN- homozigoto dominante; Nn heterozigoto; nn-homozigoto recessivo. \\
2 Número de animais analisados. \\
3 PCQ - peso da carcaça quente; ET - espessura do toucinho; PM - profundidade do músculo; \\
CM - carne magra da carcaça; COR - cor do músculo longissimus; VCOR - variação de cor ao \\
longo da carcaça. \\
Os valores seguidos de letras diferentes, na mesma linha, são diferentes (P<0,05) pelo teste \\
F. \\
4 Erros-padrão.Fonte: Bastos et al. (2001).
\end{tabular}

Bridi et al. (2003) estudaram a influencia do gene halotano na qualidade da carne suína e verificaram que músculos suínos com genótipo halotano heterozigoto apresentaram valores inferiores de $\mathrm{pH}$, menor capacidade de retenção de água e uma frequência três vezes maior de carne com característica PSE que os outros animais. Já Culauet al. (2002) num estudo com o mesmo objetivo admitiram diferença no $\mathrm{pH}$ das carcaças de suínos com e sem gene halotano mas nesse caso não houve diferença estatística entre os dois, houve diferença apenas na qualidade da carne onde as carcaças sem o gene halotano apresentaram melhor qualidade mas as carcaças com o gene halotano apesar de uma pior qualidade, esses não apresentaram carne com condição PSE. 
LEITE, R.G. et al. Influência do manejo pré-abate na qualidade da carne suína visando o bemestar animal. PUBVET, Londrina, V. 8, N. 5, Ed. 254, Art. 1681, Março, 2014.

\section{Operações pré-abate}

Para Gomide et al. (2006), as operações pré-abate são etapas que antecedem o abate do animal podendo ter interferências nas suas condições psicológicas e fisiológicas influenciando na qualidade da carne, essas operações se encontram esquematizadas na figura 4.

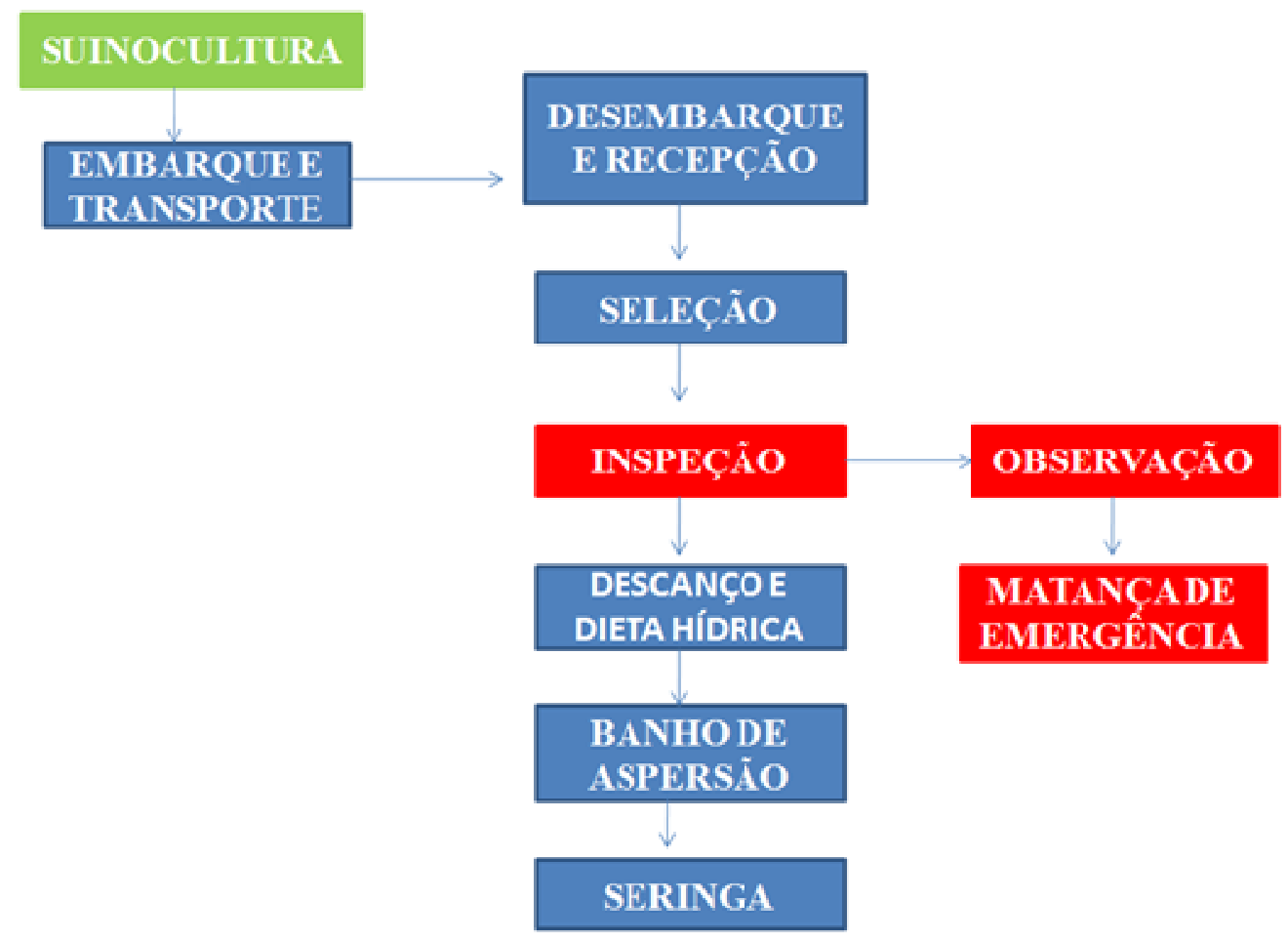

Figura 4. Fluxograma do processo de pré-abate de suínos. Fonte: adaptado de Gomide et al. (2006).

Esta etapa é de responsabilidade das agroindústrias, dos produtores e transportadores, sendo que as agroindústrias têm o dever de informar aos produtores 72 horas antes qual será a data do carregamento e a densidade do transporte. Os produtores têm o dever de preparar as instalações, a mão-deobra e realizar o jejum nos animais para que o transporte seja realizado com eficiência. Os transportadores possuem a responsabilidade sobre o transporte 
LEITE, R.G. et al. Influência do manejo pré-abate na qualidade da carne suína visando o bemestar animal. PUBVET, Londrina, V. 8, N. 5, Ed. 254, Art. 1681, Março, 2014.

de animais da granja ao abatedouro, sendo necessário a observação da ocorrência de animais com problemas de lesões ou algo que possa comprometer a vida do animal durante o manejo, além de serem responsável pelas medidas de bem-estar que envolvam essa etapa. A agroindústria além das responsabilidades citadas anteriormente é também responsável pela recepção dos animais, período de descanso no frigorífico e pelo atordoamento dos animais (DALLA COSTA et al. 2005).

\section{Coleta, tempo de jejum na granja e embarque}

O deslocamento dos animais da baia até o local de espera para o embarque deve ocorrer nas horas mais frescas do dia e após a última refeição, considerando que esta é uma atividade que provoca forte estresse no animal podendo alterar seu ritmo cardíaco, ocorrendo ainda descanso na sala de espera, com manejo adequado, pode haver diminuição de cerca de $30 \%$ da mortalidade no transporte, sendo que a grande importância desse período é que os animais consigam voltar aos níveis de batimentos cardíacos o mais próximo possível do que apresentavam na baia de terminação e ainda é importante respeitar a densidade de $0,5 \mathrm{~m}^{2} /$ animal para que diminua o efeito do estresse por familiaridade (CHEVILLON, 2000).

O tempo de jejum na granja apresenta como vantagens a diminuição da mortalidade e da ocorrência de vômitos durante o transporte, diminuição da contaminação bacteriana por meio das vezes ou da exposição do conteúdo intestinal durante a evisceração e por facilitar o procedimento de evisceração, além de normalizar os batimentos cardíacos (FAUCITANO, 2000).

Dalla Costa et al. (2010) recomendam um tempo de jejum na granja de 15 horas para que o objetivo possa ser atingido, enquanto que Santos (2004) considera que 12 horas pode ser suficiente.

O embarque dos animais é um momento crítico, uma vez que eles passam de um lugar familiar para um lugar desconhecido, com espaço escasso e com mistura de lotes (TERRA e FRIES, 2000), essa situação é discutida também por 
LEITE, R.G. et al. Influência do manejo pré-abate na qualidade da carne suína visando o bemestar animal. PUBVET, Londrina, V. 8, N. 5, Ed. 254, Art. 1681, Março, 2014.

Driessen e Geers (2000), onde relatam também alto nível de estresse no momento do carregamento.

Van Putten e Elshof (1978) citado por Zanella e Duran (2000) relataram que numa situação de embarque com inclinação de rampa de $15^{\circ}$ a frequência cardíaca do suíno aumentou $139 \%$ quanto ao valor basal, enquanto que numa situação de embarque com inclinação de rampa de $30^{\circ}$ a frequência cardíaca do suíno elevou $202 \%$ do valor basal.

O embarque provoca estresse por fatores sociais como a mistura de animais desconhecidos e por fatores não sociais como o manuseio agressivo (DRIESSEN e GEERS, 2000).

Se os suínos forem submetidos a um banho por cerca de cinco minutos em um período de clima quente $\left(>15^{\circ} \mathrm{C}\right)$, pode haver redução de $10 \%$ da temperatura corporal da superfície do suíno (CHEVILLON, 2000).

\section{Transporte}

Chevillon (2000) considera o transporte um dos manejos que mais estressam o animal por vários fatores como as condições das estradas, as condições do caminhão, o tratamento e cuidado do motorista e a duração da viagem.

Dalla Costa et al. (2005), também apontam o transporte como uma das atividades pré-abate que mais provoca estresse aos animais devido à interação homem-animal e às condições de estrutura de embarque da granja e dos caminhões, além também das misturas de lotes, podendo ocorrer mudanças de comportamento devido à hierarquia dos animais. Ainda como um dos principais problemas no transporte, temos o efeito da temperatura elevada que piora a condição do transporte, pois normalmente leva ao desenvolvimento da síndrome do estresse suíno, que é uma forte reação ocorrida pelo sistema nervoso simpático podendo resultar na morte do animal ou ainda em acidose metabólica, que em condições de metabolismo excessivo no músculo leva hipertermia e a um nível de potássio elevado no sangue que também resulta em morte do animal. 
LEITE, R.G. et al. Influência do manejo pré-abate na qualidade da carne suína visando o bemestar animal. PUBVET, Londrina, V. 8, N. 5, Ed. 254, Art. 1681, Março, 2014.

Faucitano (2000) indica como uma forma de diminuir a ocorrência de brigas por mistura de lotes, a instalação de divisórias móveis no caminhão, pois assim será possível ajustar os espaços dos compartimentos a um tamanho adequado para cada grupo.

A densidade máxima no momento do transporte é de $235 \mathrm{~kg} / \mathrm{m}^{2}$, embora haja necessidade de ajustar a densidade de acordo com o clima de cada região, sendo que uma densidade muito alta é prejudicial devido ao desconforto e a densidade muito baixa permite que os animais sejam jogados de um lado para o outro durante o trajeto (DRIESSEN e GEERS, 2000). Estudo realizado porGuárdiaet al. (1996), citado por Faucitano (2000), constataram que numa densidade acima de 2 suínos $/ \mathrm{m}^{2}$ a taxa de mortalidade aumentou de 0,04 para 0,77\% no transporte para um abatedouro na Espanha.

Zanella e Duran (2000) ressaltaram a importância do cuidado do motorista com o suíno, sendo que a condução feita por um motorista preocupado em evitar situações de freadas bruscas diminuem provocações de medo aos animais e ainda relatam que os animais que são dispostos no andar inferior do caminhão apresentam maior taxa de mortalidade que os dispostos no andar superior, sendo que esse fato está diretamente ligado com a eficiência de ventilação nessa parte do caminhão, uma vez que os sistemas de ventilação dos caminhões dependem do movimento do mesmo, o fator animal (temperatura individual, frequência respiratória e acumulo de fezes e urina individual) também influencia na qualidade do ambiente nos caminhões.

No Brasil os caminhões de dois andares são os mais utilizados no transporte de suínos, sendo que para que seja evitado o estresse devido a dificuldade de equilíbrio dos animais é recomendado que o piso dos caminhões tenha revestimento emborrachado com $10 \mathrm{~mm}$ de espessura e superfície de botões, pois além desse tipo de piso possuir propriedade antiderrapante ainda possibilita que os ruídos sejam amenizados (GOMIDE et al., 2006).

Em um estudo sobre dois tipos de carrocerias, simples e dupla, Dalla Costa et al. (2006) constataram que os suínos que foram transportados em carrocerias simples apresentaram maior número de lesões ocasionadas por 
LEITE, R.G. et al. Influência do manejo pré-abate na qualidade da carne suína visando o bemestar animal. PUBVET, Londrina, V. 8, N. 5, Ed. 254, Art. 1681, Março, 2014.

brigas, provavelmente por que esses animais passaram por mistura de lotes no carregamento para completar o número de animais por compartimento.

Faucitano (2000) recomenda o caminhão de dois andares como o ideal para o transporte de suínos, pois esse modelo possibilita que o colaborador entre e descarregue os animais sem maiores estresses e comenta ainda que o nível em que os animais se dispõem dentro do caminhão tem influencia na qualidade da carne devido aos danos causados (Tabela 4).

Tabela 4. Valores médios de dano na pele e incidência de rigor rápido (\%) em suínos de acordo com o nível de transporte.

\begin{tabular}{|c|c|c|c|c|}
\hline Andar & Danos & & & $\begin{array}{lr}\text { Início } & \text { rápido do } \\
\text { rigor } & \text { mortis } \\
(\%)^{* *} & \end{array}$ \\
\hline & Pernil & Meio & Paleta & Paleta \\
\hline $\begin{array}{l}\text { Inferior } \\
\text { Superior }\end{array}$ & $\begin{array}{l}1.40 \\
1.27\end{array}$ & $\begin{array}{l}1.75 \\
1.43\end{array}$ & $\begin{array}{l}1.12 \\
1.09\end{array}$ & $\begin{array}{l}1.2 \\
4.2\end{array}$ \\
\hline
\end{tabular}

* Medido por uma escala de quatro pontos (1-nenhum dano e 4-dano grave);

** Desenvolvimento do rigor medido em uma escala de 4 pontos (1-sem rigor e 4-rigor completo) 30 minutos post mortem. Fonte: adaptado de Barton-Gadeet al. (1996), citado por Faucitano (2000).

\section{Recepção, seleção e espera}

Assim que o caminhão chega ao frigorifico é importante que os animais sejam descarregados para evitar estresse por espera e por desconforto térmico, sendo aconselhável que o número de plataformas de desembarque seja o mesmo que o de linhas de baias de espera, sendo a condição da rampa responsável pela maioria das situações de estresse que possam ocorrer nessa fase (GOMIDE et al., 2006).

Para Driessen e Geers (2000) entre as maiores vantagens do período de descanso estão as menores concentrações de glicogênio que resulta em menor queda do $\mathrm{pH}$ e menor contaminação microbiana da carcaça durante o processamento.

A ocorrência de carne PSE em suínos abatidos logo após o desembarque é elevada, enquanto que suínos submetidos a descanso de 2 a 4 horas de 
LEITE, R.G. et al. Influência do manejo pré-abate na qualidade da carne suína visando o bemestar animal. PUBVET, Londrina, V. 8, N. 5, Ed. 254, Art. 1681, Março, 2014.

descanso tem a possibilidade de se tranquilizarem e assim regularizar seu metabolismo, sistema circulatório e sistema termorregulador, quando esse período de 2 a 4 horas é muito prolongado, as condições de briga por hierarquia e socialização entre os animais tornam-se mais frequente podendo aumentar as condições de carne PSE e DFD devido principalmente à diminuição do incremento de energia (SILVEIRA, 2005).

Quanto ao tempo de descarregamento Driessen e Geers (2000) mostram que no momento do descarregamento no frigorifico para que os animais passem pelo período de descanso além de ser importante o manuseio cuidadoso, deve-se também priorizar que o descarregamento seja feito respeitando um tempo limite (Tabela 5 ).

Tabela 5.Visão geral dos transportes com \% de PSE, temperatura média ( ${ }^{\circ} \mathrm{C}$ ) no caminhão e tempo de descarregamento.

\begin{tabular}{llll}
\hline Data & PSE $(\%)$ & $\begin{array}{l}\text { Temperatura } \\
\left({ }^{\circ} \mathrm{C}\right)\end{array}$ & $\begin{array}{l}\text { Tempo de } \\
\text { descarregamento } \\
\text { (minutos) }\end{array}$ \\
\hline $25 / 01$ & 10 & 2.33 & 24 \\
$08 / 02$ & 25 & 10.1 & 28 \\
$22 / 02$ & 25 & 6.13 & 27 \\
$07 / 02$ & 45 & 11.3 & 53 \\
$21 / 03$ & 15 & 9.93 & 52 \\
$18 / 04$ & 15 & 12.5 & 12 \\
$09 / 05$ & 42 & 13.4 & 84 \\
$06 / 06$ & 0 & 16.5 & 12 \\
$20 / 06$ & 65 & 31.8 & 35 \\
$04 / 07$ & 70 & 21.6 & 29 \\
$18 / 07$ & 21 & 18.9 & 47 \\
$01 / 08$ & 32 & 24.2 & 21 \\
$22 / 08$ & 35 & 18.4 & 20 \\
\hline
\end{tabular}

Fonte: Adaptado de Driessen e Geers (2000).

A densidade na área de descanso no frigorífico não deve ser superior a 2 suínos $/ \mathrm{m}^{2}$ e nem inferior a 1 suíno $/ \mathrm{m}^{2}$, pois com área grande demais as possibilidades de ocorrer brigas aumentam, e ainda deve haver o cuidado para que os compartimentos nessa área seja o mais próximo possível do tamanho dos compartimentos dos caminhões para que não precise novamente fazer misturas de lotes (CHEVILLON, 2000). 
LEITE, R.G. et al. Influência do manejo pré-abate na qualidade da carne suína visando o bemestar animal. PUBVET, Londrina, V. 8, N. 5, Ed. 254, Art. 1681, Março, 2014.

\section{Condução ao abate}

Segundo Gomide et al. (2006), esta é uma etapa de grande importância com relação ao estresse que os suínos sofrem devido ao seu instinto de fuga, sendo que nessa etapa a localização das baias e dos corredores é de extrema importância para que a condução seja feita em um tempo menor que 3 minutos, o manejo feito com um grupo de suínos menor do que 15 também diminui os problemas na condução, caso o fluxo esteja lento é permitido o uso de picana elétrica mas apenas como complemento de materiais como painéis de plástico ou madeira.

O uso de tábua de manejo de madeira ou plástico é o mais utilizado e o mais recomendado para a condução dos animais ao box de insensibilização, porém, em algumas situações de recusa dos animais é utilizado o bastão elétrico e vocalização, o que aumenta de forma drástica o nível de estresse desses animais podendo piorar a velocidade da condução e acarretar em efeitos negativos na qualidade da carne (CHEVILLON, 2000).

Ludteket al. (2010), ao compararem suínos que foram conduzidos ao abate com o uso de pranchas de alumínio e suínos que foram conduzidos com o auxílio de bastão elétrico, encontraram resultados que estão apresentados na tabela 6, e que demonstram a importância de um manejo menos agressivo.

Tabela 6. Escores de lesões (\%) em carcaça suína em função do uso de bastão elétrico e painel, segundo diferentes cortes.

\begin{tabular}{llllllllll}
\hline & 1-Ausencia & 2-Leve & \multicolumn{3}{c}{ 3-Moderada } & \multicolumn{2}{c}{ 4-Severa } & \\
\cline { 2 - 8 } Amostra & G-1 & G-2 & G-1 & G-2 & G-1 & G-2 & G-1 & G-2 & P* \\
\hline $\begin{array}{l}\text { Pernil } \\
\text { (\%) }\end{array}$ & 54,17 & 69,23 & 37,50 & 30,77 & 8,33 & 0,00 & 0 & 0 & 0,24 \\
$\begin{array}{l}\text { Corpo } \\
\text { \%) }\end{array}$ & 33,33 & 30,77 & 46,15 & 46,15 & 16,67 & 23,08 & 0 & 0 & 0,85 \\
$\begin{array}{l}\text { Paleta } \\
(\%)\end{array}$ & 87,50 & 57,69 & 34,62 & 34,62 & 0 & 7,69 & 0 & 0 & 0,05 \\
\end{tabular}
Lesões da pele são medidas por um escore de 4 pontos: 1 e 2 representam valores aceitáveis. G1- Baixo estresse (utilização de pranchas de alumínio para movimentar os animais); G2- Alto estresse (utilização de bastão elétrico); P* significância. Fonte: adaptado de Ludtkeet al. (2010). 
LEITE, R.G. et al. Influência do manejo pré-abate na qualidade da carne suína visando o bemestar animal. PUBVET, Londrina, V. 8, N. 5, Ed. 254, Art. 1681, Março, 2014.

\section{Banho de aspersão e seringa}

O banho de aspersão deve possuir $1,5 \mathrm{~atm}$ de pressão e durar no mínimo 3 minutos para que lave profusamente os suínos (BRASIL, 1995), porém, Venturini et al. 2007, relatam que o banho pode ter $1 \mathrm{~atm}$ de pressão usando o mesmo tempo mínimo de 3 minutos, e tem como finalidade fazer uma prélavagem no couro e ainda auxiliar no fator anti-estresse devido a dificuldade do animal realizar a regulação térmica.

Segundo Pacheco e Yamanaka (2006), além de ser indispensável à instalação do banho de aspersão, a seringa devem ir se afunilando conforme a aproximação com o boxe de atordoamento para facilitar que os animais sigam o trajeto sem maiores alterações comportamental.

Araújo et al. (2011), utilizaram três períodos de aspersão (30 minutos com interrupção, 60 minutos com interrupção e 180 minutos sem interrupção) em que avaliaram níveis de substâncias indicadoras de estresse presentes no sangue (cortisol, creatinaquinase e lactato), o estudo não apresentou diferença estatística entre os períodos, conforme a tabela 7.

Tabela 7. Valores médios e erro-padão dos indicadores de estresse: cortisol, lactato e creatinaquinase (CPK), nos três tempos de aspersão propostos no experimento.

\begin{tabular}{llll}
$\begin{array}{l}\text { Indicadores de } \\
\text { estresse }\end{array}$ & Contínuo & 60 minutos & 30 minutos \\
\hline Cortisol $\mu \mathrm{g} / \mathrm{dL}$ & $8,03-0,95^{\mathrm{a}}$ & $7,92-0,68^{\mathrm{a}}$ & $6,89-0,70^{\mathrm{a}}$ \\
Lactato (mg/dL) & $9,64-0,62^{\mathrm{a}}$ & $10,80-0,60^{\mathrm{a}}$ & $11,00-0,55^{\mathrm{a}}$ \\
CPK (unidade/L) & 4932,68 & $-3596,77^{\mathrm{a}}$ & $-3861,70$ \\
& $1351,6^{\mathrm{a}}$ & $616,61^{\mathrm{a}}$ & $858,18^{\mathrm{a}}$ \\
\hline
\end{tabular}

*Letras diferentes na mesma linha indicam haver diferença estatística significativa $(p<0,05)$ pelo teste $\mathrm{t}$ de Student, protegido pela significância do teste $\mathrm{F}$ global. Fonte: adaptado de Araújo et al. (2012).

A condução para o box de insensibilização é uma ação extremamente estressante para os suínos, uma vez que eles passam de uma situação em que permaneciam em grupo com movimentos livres, para uma fila onde ficam individualizados na seringa de abate. A seringa deve ser o mais curta possível 
LEITE, R.G. et al. Influência do manejo pré-abate na qualidade da carne suína visando o bemestar animal. PUBVET, Londrina, V. 8, N. 5, Ed. 254, Art. 1681, Março, 2014.

para permitir apenas um suíno por vez, evitando que ocorram situações de monta, o que aumenta a possibilidade de lesões na pele (GOMIDE et al., 2006).

\section{Considerações finais}

De acordo com os trabalhos revisados, o bem estar animal em suínos é de extrema importância não só para que esses animais tenham seus hábitos respeitados durante toda sua produção, quanto para que a qualidade da carne não sofra nenhum efeito negativo devido a situações de estresse que ocorrem principalmente no manejo pré-abate (jejum na granja, carregamento, transporte seguindo até o momento de contenção para a insensibilização).

Além da grande influência do estresse sofrido pelo animal durante todo o manejo pré-abate, deve ser considerada a carga genética dos suínos atuais que os tornam mais susceptíveis ao estresse, sendo responsável por essa maior susceptibilidade, o gene halotano. Diante desse estudo fica comprovado a necessidade de mudanças cada vez maiores quanto ao manejo realizado com os suínos tanto no setor de produção como no setor de abate além de ser necessária também a implantação de programas de melhoramento genético que possam chegar à obtenção de suínos com grande deposição de carne magra sem a presença do gene halotano.

\section{REFERÊNCIAS}

ARAÚJO, A. P.; DALLA COSTA, O. A.; LUDTKE, C. B. et al. Uso de aspersão em suínos nas baias de espera: implicações no bem-estar.In: CONGRESSO BRASILEIRO DE MEDICINA VETERINÁRIA, 38., 2011. Florianópolis. Anais... Florianópolis: SBMC/Somevesc, 2011. 1 CDROM.

BASTOS, R. G.; FEDERIZZI, J.; DESCHAMPS, J. C; et al. Efeito do gene do estresse suíno sobre características de quantidade e qualidade de carcaça. Revista Brasileira de Zootecnia,v.30, n.1,p.37-40, 2001.

BRAGAGNOLO, N.; AMAYA, D. B. R. Teores de colesterol, lipídios totais e ácidos graxos em cortes de carne suína. 2002. Disponível em: < http://www.scielo.br/pdf/cta/v22n1/a18v22n1.pdf>. Acesso em: 17 maio 2012.

BRASIL. Ministério da Agricultura Pecuária e Abastecimento. Instrução Normativa n. 711 de 01 de novembro de 1995. Aprova as normas técnicas de instalações e equipamentos para abate e industrialização de suínos. Diário Oficial da União, Brasília, seção 1, p. 17625. 
BRAUN, J. A. O bem-estar animal na suinocultura. In: CONFERÊNCIA INTERNACIONAL VIRTUAL SOBRE QUALIDADE DE CARNE SUÍNA. 1, Concórdia, SC. Anais... Concórdia: Embrapa Suínos e Aves, 2000. p. 1-3. CD-ROOM.

BRIDI, A. M.; OLIVEIRA, A. R.; FONSECA, N. A. N. et al. Efeito do genótipo halotano, da ractopamina e do sexo do animal na qualidade da carne suína. Revista Brasileirade Zootecnia, v.35, n.5, p.2027-2033, 2006.

BRIDI, A. M.; RUBENSAM, J. M.; NICOLAIEWSKY, S.; et al. Efeito do genótipo halotano e de diferentes sistemas de produção na qualidade da carne suína. Revista Brasileira de Zootecnia, v.32, n.6, p.1362-1317, 2003.

BRIDI, AM. M. Transformações post mortemdo músculo em carne. 2005. Disponível em: < http://www.uel.br/pessoal/ambridi/Carnesecarcacas.htm>. Acesso em: 26 junho 2012.

BROOM, D. M.; MOLENTO, C. F. M. Bem-estar animal: conceitoe questõesrelacionadas. 2004. Disponível em: < http://www.freewebs.com/hotzel/Molento2004.pdf> Acesso em: 27 abril 2012.

CERUTTI, M. Programa de garantia da qualidade para a carne suína na indústria brasileira. In: SEMINÁRIO INTERNACIONAL SOBRE PRODUÇÃO, MERCADO E QUALIDADE DA CARNE DE SUÍNOS - AVESUI. 2, Florianópolis, SC. Anais... Concórdia: Embrapa Suínos e Aves, 2003. p. 74-94. CD-ROOM.

CHEVILLON, P. O bem-estar dos suínos durante o pré-abate e no atordoamento. In: CONFERÊNCIA INTERNACIONAL VIRTUAL SOBRE QUALIDADE DE CARNE SUÍNA. 1, Concórdia, SC. Anais... Concórdia: Embrapa Suínos e Aves, 2000. p. 152-168. CD-ROOM.

CULAU, P. O. V.; LÓPEZ, J.; RUBENSAM, J. M. A contribuição do gene halotano sobre as características de qualidade da carne suína. Ciência Rural. SantaMaria, v.32, n.1, p.115-119. 2002.

DALLA COSTA, O. A.; BERTOL, T. M.; LUDKE, J. V.; et al. Efeito do manejo pré-abate e da posição do box dentro da carroceria sobre o perfil hormonaldos suínos.Concórdia-SC: Embrapa Suínos e Aves, 2005 (Comunicado Técnico 406).

DALLA COSTA, O. A.; FAUCITANO, L.; COLDEBELLA, A.; et al. Efeito da época do ano e do modelo de carroceria sobre a freqüência de lesões na carcaça dossuínos.ConcórdiaSC: Embrapa Suínos e Aves, 2006 (Comunicado Técnico 421).

DALLA COSTA, O. A.; LUDKE, J. V.; COSTA, M. J. R. P.; et al. Efeitos das condições pré-abate sobre a qualidade da carne de suínos pesados. Archivos de Zootecnia, v.59,n.227, p.391402, 2010.

DRIESSEN, B.; GEERS, R. Estresse durante o transporte e qualidade da carne suína. Uma visão europeia. In: CONFERÊNCIA INTERNACIONAL VIRTUAL SOBRE QUALIDADE DE CARNE SUÍNA. 1, Concórdia, SC. Anais... Concórdia: Embrapa Suínos e Aves, 2000. p. 41-54. CDROOM.

FARIA, R. F. Estudo da carneDFD (dark, firmanddry) em suínos. In: CURSO DE ORIGEM E INSPEÇÃO DE PRODUTOS DE ORIGEM ANIMAL. Andradina- SP, 2008. p. 1-34. CD-ROOM.

FARM ANIMAL WELFARE COUNCIL. Updates the five freedoms.Veterinary Record, London, $v$. 17, p. 357, 1992.

FAUCITANO, L. Efeitos do manuseio pré-abate sobre o bem-estar e sua influência sobre a qualidade de carne. In: CONFERÊNCIA INTERNACIONAL VIRTUAL SOBRE QUALIDADE DE CARNE SUÍNA. 1, Concórdia, SC. Anais... Concórdia: Embrapa Suínos e Aves, 2000. p. 55-75. CD-ROOM.

FAUCITANO, L. Efeitos do manuseio pré-abate sobre o bem-estar e sua influência sobre a qualidade de carne. In: CONFERÊNCIA INTERNACIONAL VIRTUAL SOBRE QUALIDADE DE 
CARNE SUÍNA. 1, Concórdia, SC. Anais... Concórdia: Embrapa Suínos e Aves, 2000. p. 55-75. CD-ROOM.

FÁVERO, J.A.; BELLAVER, C. Produção de carne de suínos. In: CONGRESSO BRASILEIRO DE CIÊNCIA E TECNOLOGIA DE CARNES, 2001, Campinas. Anais... Campinas: CTC/ITAL, 2001. p.2-25.

GOMIDE, L. A. M.; RAMOS, E. M.; FONTES, P. R. Abate de suínos. In: . Tecnologia de abate e tipificação de carcaças. Viçosa-MG: UFV, 2006. p. 158-194.

LUDTKE, C. B.; SILVEIRA, E. T. F.; BERTOLONI, W. et al. Bem-estar e qualidade de carne de suínos submetidos a diferentes técnicas de manejo pré-abate. Revista Brasileira deSaúde e Produção Animal, v.11, n.1, p.231-241, 2010.

MACHADO FILHO, L. C. P.; HOTZEL, M. J. Bem-estar dos suínos. In: SEMINÁRIO INTERNACIONAL DE SUINOCULTURA. 5, São Paulo, SP.Anais... 2000. p. 70-82. CD-ROOM.

MURRAY, A. C. Reduzindo perdas da porteira da granja até o abatedouro - uma perspectiva canadense. In: CONFERÊNCIA INTERNACIONAL VIRTUAL SOBRE QUALIDADE DE CARNE SUÍNA. 1, Concórdia, SC. Anais... Concórdia: Embrapa Suínos e Aves, 2000. p. 76-87. CDROOM.

PACHECO, J. W.; YAMANAKA, H. T. Guia técnico de abate de bovinos e suínos. CETESBSão Paulo. 2006. Disponível em: <http://www.cetesb.sp,gov.br>. Acesso em: 15 abril 2012.

ROÇA, R.O. Modificações pós-morte da carne. UNESP - São Paulo. 2001. Disponível em: <http://www.fca.unesp.br> Acesso em: 29 abril. 2012.

RUBENSAM, J. M. 2000. Transformações post mortem e qualidade da carne suína. In: CONFERÊNCIA INTERNACIONAL VIRTUAL SOBRE QUALIDADE DE CARNE SUÍNA. 1, Concórdia, SC. Anais... Concórdia: Embrapa Suínos e Aves, 2000. p. 89-99. CD-ROOM.

SANTOS, F. A. Bem-estar dos suínos. Revista Eletrônica Nutritime, v.1, n3, p 101-116, 2004.

<http://www.nutritime.com.br/arquivos_internos/artigos/012V1N3P101_116_NOV2004.pdf>

Acesso em: 15 abril 2012.

SARCINELLI, M. F.; VENTURINI, K. S.; SILVA, L. C. Características da carnesuína. 2007. Disponível em: < http://www.agais.com/telomc/b00907_caracteristicas_carnesuina.pdf > . Acesso em: 27 abril 2012.

SCHAFER. S. M. Meatevaluationhandbook. 2001. Disponível em: <http://www.unce.unr.edu/4H/programs/stem/files/pdf/4-HManualMeatJudging.pdf>. Acesso em: 12 abril 2012.

SILVEIRA, E.T. F. Bem estar animal e qualidade da carne suína. In: SIMPÓSIO GOIANO DE AVICULTURA E SIMPÓSIO GOIANO DE SUINOCULTURA-AVESUI CENTRO-OESTE. Goiania-GO. Anais...Goiania, 2005. p. 16-26. CD-ROOM.

TALAMINI, E.; FERREIRA, G. M. V. Mercado internacional da carne suína: variáveis que influenciam no número de países exportadores. In: TEXTOS PARA DISCUÇÃOUNIVERSIDADE DE PASSO FUNDO. Passo Fundo-RS. 2006. p. 1-19.

TERRA, N. N.; FRIES, L. L. M. A qualidade da carne suína e sua industrialização. In: CONFERÊNCIA INTERNACIONAL VIRTUAL SOBRE QUALIDADE DE CARNE SUÍNA. 1, Concórdia, SC. Anais... Concórdia: Embrapa Suínos e Aves, 2000. p. 147-151. CD-ROOM.

TRAMONTINI. P. Consumo da carne suína a experiência brasileira. In: SEMINÁRIO INTERNACIONAL DE SUINOCULTURA. 5, São Paulo, SP. Anais... São Paulo, 2000. p. 6-11. CDROOM.

VENTURINI, K. S.; SARCINELLI, M. F.; SILVA, L. C. Abate de suínos. Boletim técnico. Universidade Federal do Espírito Santo, 2007. 
WARRIS, P. D.; BROWN, S. N. Bem-estar de suínos e qualidade de carne: uma visão britânica. In: CONFERÊNCIA INTERNACIONAL VIRTUAL SOBRE QUALIDADE DE CARNE SUÍNA. 1, Concórdia, SC. Anais... Concórdia: Embrapa Suínos e Aves, 2000. p. 17-20. CD-ROOM.

ZANELLA, A. J.; DURAN, O. Bem-estar de suínos durante o embarque e o transporte: uma visão norte-americana. In: CONFERÊNCIA INTERNACIONAL VIRTUAL SOBRE QUALIDADE DE CARNE SUÍNA. 1, Concórdia, SC. Anais... Concórdia: Embrapa Suínos e Aves, 2000. p. 21-33. CD-ROOM. 